\title{
Effects of the Long-Term (7-9 Months) Feeding of Iodine-Enriched Eggs on Lipid Metabolism of Rats ${ }^{1}$
}

\author{
Shinichiro Katamine, ${ }^{2}$ Nobuyuki Hoshino, ${ }^{2}$ Koji Totsuka, ${ }^{2}$ \\ and Masashige SuZUKI ${ }^{3}$ \\ ${ }^{2}$ Research Center, Nihon Nosan Kogyo K. K., \\ Funabashi, Chiba 273, Japan \\ ${ }^{3}$ Laboratory of Biochemistry of Exercise and Nutrition, \\ Institute of Health and Sports Sciences, \\ The University of Tsukuba, \\ Niihari-gun, Ibaraki 305, Japan
}

(Received June 2, 1982)

\begin{abstract}
Summary The effect of long-term (7-9 months) feeding of a diet containing iodine-enriched eggs, which had considerably higher amounts of iodine than ordinary eggs, was studied on the lipid metabolism in rats. A laboratory powder chow was added at $1 \%(\mathrm{w} / \mathrm{w})$ level with ordinary egg powder (Ordinary egg diet as control: $35.1 \mu \mathrm{g}$ iodine $/ 100 \mathrm{~g}$ diet) or iodineenriched egg powder (Iodine-enriched egg diet: $392.2 \mu \mathrm{g}$ iodine/100 g diet). The animals were meal-fed twice a day and allowed to take daily voluntary running exercise in wheels for $24 \mathrm{hr}$. The long-term feeding with iodineenriched eggs did not influence body weight gain, food intake, voluntary running activity, weights of several organs and adipose tissues; and lipid concentrations in several organs and tissues. However, the serum lipid levels were decreased after the feeding of iodine-enriched eggs. A decrease in triacylglycerol (TG) level was significant $(p<0.05)$. The long-term feeding with iodine-enriched eggs resulted in a reduced hepatic-intestinal TG production rate and also an enhanced TG removal rate from blood. Furthermore, skeletal muscle and adipose tissue lipoprotein lipase activity was significantly elevated with the feeding of iodine-enriched eggs. These results suggest that the lowering effect of blood TG level with feeding of iodine-enriched eggs may be mediated by either a reduced hepaticintestinal TG production or an enhanced peripheral removal of circulating TG. Serum total iodine concentration was 5 times higher in the iodineenriched egg fed rats as compared to controls, but the serum concentrations of thyroid stimulating hormone and thyroid hormones as well as the thyroid total iodine content were not different between the two
\end{abstract}

\footnotetext{
${ }^{1}$ Studies on Nutritional Consequences of Iodine-enriched Eggs (Part 2).

2 片峯伸一郎, 星野信行, 戸塚耕二， ${ }^{3}$ 鈴木正成
} 
dietary groups of animals. Thus, the present study did not demonstrate any relationship between the hypotriacylglycerolemic effect of iodineenriched eggs and the serum levels of thyroid relating hormones.

Key Words lipid metabolism, long-term feeding, iodine-enriched egg, thyroid stimulating hormone, thyroid hormone, thyroid iodine, TG production and removal, lipoprotein lipase, rat

A new type of hen's eggs which contain considerably higher amounts of iodine $(400-700 \mu \mathrm{g} / \mathrm{egg})$ than ordinary eggs was developed in 1976 and has been sold in Japan. However, the nutritional consequences of the iodine-enriched eggs have not been sufficiently elucidated yet.

Our previous investigation showed that the feeding of iodine-enriched eggs to growing rats for 10 weeks increased the lipoprotein lipase activities in the adipose tissue and skeletal muscle simultaneously with increasing glycogen stores in the liver and skeletal muscle(1). The possibility was suggested, therefore, that iodineenriched eggs may influence the lipid metabolism of rats.

In the present study, we investigated the lipid metabolism of rats fed iodineenriched eggs for 7-9 months, comparing with rats fed ordinary eggs. Our results strongly suggested that the iodine-enriched eggs could reduce the hepatic-intestinal TG production and enhance the circulating TG removal by peripheral tissues.

\section{EXPERIMENTAL}

Animals and feeding conditions. The feeding conditions were similar to those previously reported (1). Male Sprague-Dawley rats of 4 weeks of age (Japan CLEA Inc., Tokyo) were ad libitum fed on a commercial diet (Labo MR Stock; Nihon Nosan Kogyo K. K., Yokohama) as a basal diet for one week. Then the feeding pattern was changed to meal-feeding twice a day $(08.00-09.00 \mathrm{hr}$ and 20.00 $21.00 \mathrm{hr}$ ) according to the method by Suzuki et al.(2). At 6 weeks old rats were housed individually in cages attached with revolving wheels $(10 \mathrm{~cm}$ width and $1.25 \mathrm{~m}$ circumference). At 7 weeks of age rats were divided into two experimental groups to have approximately the same mean body weight and voluntary running activity, then they were fed on experimental diets. The animal room was maintained at $25 \pm 2{ }^{\circ} \mathrm{C}$ with lighting between $7 \mathrm{AM}$ and $7 \mathrm{PM}$. Drinking water was supplied $a d$ libitum throughout the experimental period. Body weight was measured twice a week and food intake on two successive days every week. Voluntary running distance was calculated from the revolution number which was recorded by a counter on each cage.

Diets. To prepare experimental diets ordinary eggs or iodine-enriched eggs were produced by White Leghorn laying hens fed on a commercial ration or the ration supplemented with seaweed powder and inorganic iodine, respectively. Each liquid whole egg was spray-dried to obtain the egg powder. The experimental diets 
Table 1. Chemical composition of diets.

\begin{tabular}{lrrr}
\hline & & $\begin{array}{c}\text { Ordinary } \\
\text { egg diet }\end{array}$ & $\begin{array}{c}\text { Iodine-enriched } \\
\text { egg diet }\end{array}$ \\
\hline Moisture & $(\mathrm{o})$ & 9.2 & 9.3 \\
Crude protein & $(\mathrm{g} / 100 \mathrm{~g})$ & 19.7 & 19.6 \\
Crude fat & $(\mathrm{g} / 100 \mathrm{~g})$ & 4.9 & 4.7 \\
Crude fiber & $(\mathrm{g} / 100 \mathrm{~g})$ & 6.5 & 6.7 \\
Crude ash & $(\mathrm{g} / 100 \mathrm{~g})$ & 6.9 & 6.8 \\
Iodine & $(\mu \mathrm{g} / 100 \mathrm{~g})$ & 35.1 & 392.2 \\
\hline
\end{tabular}

Table 2. Iodine content of egg powders.

\begin{tabular}{ccc}
\hline & $\begin{array}{c}\text { Ordinary } \\
\text { egg powder }\end{array}$ & $\begin{array}{c}\text { Iodine-enriched } \\
\text { egg powder }\end{array}$ \\
\hline Iodine $(\mathrm{mg} / \mathrm{kg})$ & 3.1 & 361.0 \\
\hline
\end{tabular}

were prepared by adding ordinary egg or iodine-enriched egg powder at the amount of $1 \%(\mathrm{w} / \mathrm{w})$ to the basal diet. These diets gave rats $2-5 \mathrm{~g}$ of liquid whole $\mathrm{egg} / \mathrm{kg}$ body weight per day over the experimental period. The chemical composition of ordinary egg diet and iodine-enriched egg diet is shown in Table 1, and the iodine content of those egg powders in Table 2. Other chemical compositions of these two egg powders were almost the same as those described in our previous paper (1).

Preparation of samples for analysis. At the age of 8 months after 7 months of meal-feeding on experimental diets, the blood samples were obtained from the tail veins of rats of both groups at $08.00 \mathrm{hr}$ (just before the morning meal) and $13.00 \mathrm{hr}$ ( $4 \mathrm{hr}$ after the meal), and the rats were sacrificed by decapitation at $20.00 \mathrm{hr}$ (just before the evening meal) on the same day. The heart, lungs, liver, kidneys, adrenals, spleen, testes, brain, thyroid, and perirenal and epididymal adipose tissues were removed and weighed. The soleus muscle and abdominal aorta were also obtained. The separated blood serum and tissue samples were frozen at -20 and $-80^{\circ} \mathrm{C}$ until assay, respectively.

Analytical methods. Serum triacylglycerol (TG) was determined by the method of Fletcher (3), total cholesterol according to the method of Zurkowski(4) and phospholipid by using the Phospholipids-Test kit (Wako Pure Chemical Industries, Ltd., Tokyo). Total lipid in several organs and tissues was extracted as described by Folch et al.(5) and measured gravimetrically. The extracted lipid was also determined for $\mathrm{TG}$, total cholesterol and phospholipid as mentioned above. Lipoprotein lipase [EC 3.1.1.3] (LPL) activity in soleus muscle, heart and epididymal adipose tissue was measured by the procedure as described by Suzuki et al. (6) mainly based on the methods of De Gasquet and Péquignot (7) and Trout et al. (8). The LPL activity was expressed as $\mu \mathrm{mol}$ free fatty acids released $/ \mathrm{hr} / \mathrm{g}$ of wet 
tissue. Serum thyroid stimulating hormone (TSH) was assayed by the double antibody radioimmunoassay using the TSH-RIA kit (Eiken Chemical Co., Ltd., Tokyo). Determinations for serum thyroxine and triiodothyronine were performed with the $\mathrm{T}_{4^{-}}$and $\mathrm{T}_{3}$-RIA kit (Dinabbot Radioisotope Laboratory Co., Ltd., Tokyo), respectively. Total iodine in serum and thyroid was determined by the Sandell-Kolthoff method (9) after acid digestion of the samples (10).

Studies for $T G$ production and $T G$ removal in vivo. Hepatic-intestinal TG production rate and peripheral TG removal rate were estimated in the resting period of a day on rats fed experimental diets for about 9 months. For TG production rate study $(11,12)$, the rats of both groups were fasted for $14 \mathrm{hr}$ from $21.00 \mathrm{hr}$, to avoid the direct effect of the experimental diets, and then orally given a $60 \%$ sugar mixture solution containing both $30 \%$ glucose and $30 \%$ fructose $(1 \mathrm{ml} / 100 \mathrm{~g}$ body weight $)$ to promote the lipogenesis in the animals. Three hours later a $30 \%$ Triton WR-1339 solution was injected into the tail veins $(0.2 \mathrm{ml} / 100 \mathrm{~g}$ body weight $)$. TG accumulation in the blood during the additional $2 \mathrm{hr}$ was determined. For TG removal rate study $(11,13)$, a $10 \%$ TG-containing intralipid emulsion was injected into the tail veins $(0.2 \mathrm{ml} / 100 \mathrm{~g}$ body weight $)$ after the rats were fasted for $17 \mathrm{hr}$ from $21.00 \mathrm{hr}$, and TG removal from the blood between 15 and $30 \mathrm{~min}$ after the injection was evaluated. The same rats of both groups were used for both the TG production rate and TG removal rate studies, however, the TG production rate experiment was carried out 10 days after the TG removal rate experiment.

Statistical analyses were performed by the Student's $t$-test.

RESULTS

Growth, food intake, voluntary running activity and weights of organs and tissues (Fig. 1 and Table 3)

Throughout the experimental period of 7 months, there was no significant difference between the two dietary groups of animals in weight gain, food intake and voluntary running activity. The voluntary running activity increased to a peak of around $12 \mathrm{~km} / \mathrm{rat} /$ day at the age of 8 weeks, and then gradually decreased until 6 months old to reach a low level of 1 to $2 \mathrm{~km} / \mathrm{rat} / \mathrm{day}$. After 7 months of feeding, the two dietary groups of rats did not show any significant difference in weights of several organs including thyroid gland and two adipose tissues.

\section{Concentration of lipids in several organs and tissues (Table 4)}

The mean concentrations of total lipid, TG, total cholesterol and phospholipid in the liver, kidney, brain, epididymal adipose tissue and aorta were not statistically different between the two dietary groups of animals after the experimental period of 7 months.

\section{Concentration of serum lipids (Fig. 2)}

The mean serum concentrations of TG, total cholesterol and phospholipid 


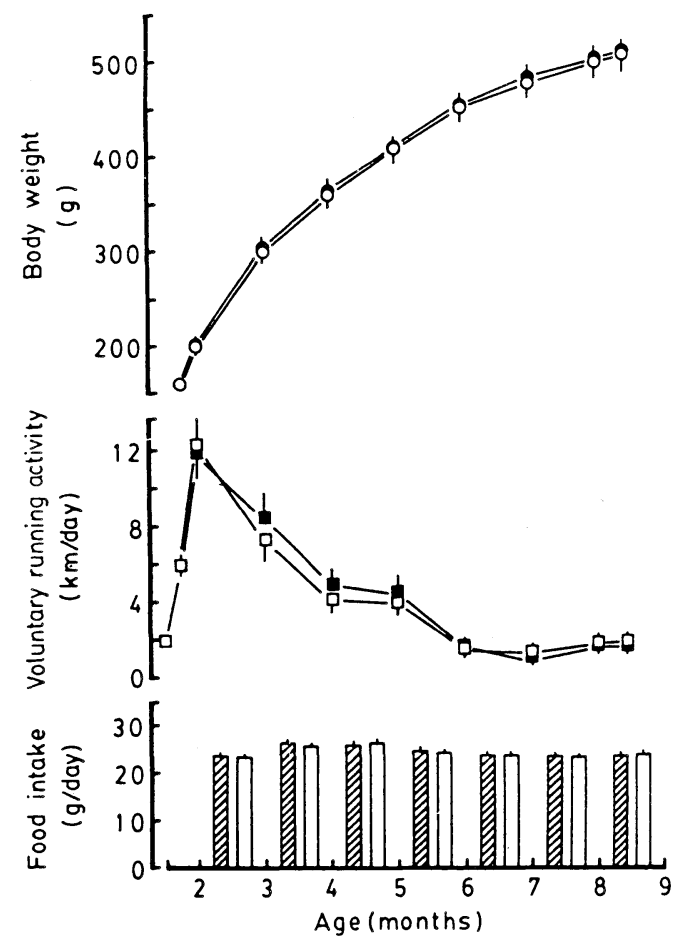

Fig. 1. Food intake, voluntary running activity and weight gain of rats meal-fed an ordinary egg diet (13 rats) or an iodine-enriched egg diet (13 rats) during the experimental period of 7 months. Vertical line represents standard error of the mean. Ordinary egg diet group: $\bullet, \mathbf{a}$, and $\mathbb{Z W W}$. Iodine-enriched egg diet group: $\bigcirc$, $\square$, and

determined 7 months after the dietary treatment were consistently lower at three time points in a day in the iodine-enriched egg fed rats than those in controls. In particular, TG level was significantly lower $(p<0.05)$ at both 13.00 and $20.00 \mathrm{hr}$. Additionally, the increments in the serum lipid levels $4 \mathrm{hr}$ after the morning meal were smaller in the iodine-enriched egg fed rats than in controls, although both groups of animals consumed almost equal amounts of food at the meal time.

\section{$T G$ production rate and $T G$ removal rate (Table 5)}

In the iodine-enriched egg fed rats, there was a significantly lower TG production rate $(p<0.05)$ and oppositely a significantly higher TG removal rate $(p<0.05)$, as compared with controls, after the experimental period of 9 months.

\section{LPL activity in soleus muscle, heart and adipose tissue (Table 6)}

The LPL activity in both soleus muscle and epididymal adipose tissue of the iodine-enriched egg fed rats was significantly higher than that of controls, while that 
Table 3. Weights of organs and adipose tissues of rats meal-fed an ordinary egg diet or an iodine-enriched egg diet for 7 months.

\begin{tabular}{lrrc}
\hline & & \multicolumn{2}{c}{ Dietary group } \\
\cline { 3 - 4 } & & $\begin{array}{c}\text { Ordinary } \\
\text { egg diet }(8)^{\mathrm{a}}\end{array}$ & $\begin{array}{c}\text { Iodine-enriched } \\
\text { egg diet (8) }\end{array}$ \\
\hline Heart & $(\mathrm{g})$ & $0.26 \pm 0.01$ & $0.27 \pm 0.01$ \\
Lungs & $(\mathrm{g})$ & $0.36 \pm 0.02$ & $0.41 \pm 0.05$ \\
Liver & $(\mathrm{g})$ & $3.19 \pm 0.09$ & $2.96 \pm 0.12$ \\
Kidneys & $(\mathrm{g})$ & $0.59 \pm 0.01$ & $0.58 \pm 0.02$ \\
Adrenals & $(\mathrm{mg})$ & $10.5 \pm 0.7$ & $10.2 \pm 0.7$ \\
Spleen & $(\mathrm{g})$ & $0.15 \pm 0.01$ & $0.16 \pm 0.01$ \\
Testes & $(\mathrm{g})$ & $0.80 \pm 0.02$ & $0.82 \pm 0.02$ \\
Brain & $(\mathrm{g})$ & $0.44 \pm 0.01$ & $0.42 \pm 0.01$ \\
Thyroid & $(\mathrm{mg})$ & $5.16 \pm 0.41$ & $4.90 \pm 0.36$ \\
Perirenal fat pads & $(\mathrm{g})$ & $2.11 \pm 0.23$ & $2.09 \pm 0.33$ \\
Epididymal fat pads & $(\mathrm{g})$ & $1.66 \pm 0.15$ & $1.61 \pm 0.24$ \\
\hline
\end{tabular}

${ }^{a}$ Number of rats. Values are means \pm SEM per $100 \mathrm{~g}$ of body weight.

Table 4. Concentration of lipids in several organs and tissues of rats meal-fed an ordinary egg diet or an iodine-enriched egg diet for 7 months.

\begin{tabular}{|c|c|c|c|c|c|}
\hline & Dietary group & Total lipid & $\begin{array}{l}\text { Triacyl- } \\
\text { glycerol }\end{array}$ & $\begin{array}{c}\text { Total } \\
\text { cholesterol }\end{array}$ & Phospholipid \\
\hline Liver & $\begin{array}{l}\text { Ordinary egg } \\
\text { I-enriched egg }\end{array}$ & $\begin{array}{l}55.8 \pm 2.4^{\mathrm{a}} \\
59.6 \pm 4.0\end{array}$ & $\begin{array}{c}(\mathrm{mg} / \mathrm{g} \text { of } \\
10.6 \pm 1.4 \\
12.4 \pm 1.8\end{array}$ & $\begin{array}{l}\text { wet tissue) } \\
2.7 \pm 0.1 \\
2.6 \pm 0.1\end{array}$ & $\begin{array}{l}31.3 \pm 1.0 \\
31.5 \pm 1.0\end{array}$ \\
\hline Kidney & $\begin{array}{l}\text { Ordinary egg } \\
\text { I-enriched egg }\end{array}$ & $\begin{array}{l}39.7 \pm 2.2 \\
38.0 \pm 2.0\end{array}$ & $\begin{array}{l}4.8 \pm 0.5 \\
4.1 \pm 0.6\end{array}$ & $\begin{array}{l}4.7 \pm 0.2 \\
4.8 \pm 0.1\end{array}$ & $\begin{array}{l}28.4 \pm 0.9 \\
27.8 \pm 0.5\end{array}$ \\
\hline Brain & $\begin{array}{l}\text { Ordinary egg } \\
\text { I-enriched egg }\end{array}$ & $\begin{array}{r}101.7 \pm 5.4 \\
97.9 \pm 5.0\end{array}$ & $\begin{array}{l}0.3 \pm 0.1 \\
0.2 \pm 0.1\end{array}$ & $\begin{array}{l}18.5 \pm 1.2 \\
18.8 \pm 0.6\end{array}$ & $\begin{array}{l}47.8 \pm 0.7 \\
46.7 \pm 0.9\end{array}$ \\
\hline $\begin{array}{l}\text { Epididymal } \\
\text { adipose tissue }\end{array}$ & $\begin{array}{l}\text { Ordinary egg } \\
\text { I-enriched egg }\end{array}$ & $\begin{array}{l}882.2 \pm 11.1 \\
871.8 \pm 14.8\end{array}$ & $\begin{array}{l}727.4 \pm 12.8 \\
724.0 \pm 16.7\end{array}$ & $\begin{array}{l}8.2 \pm 0.4 \\
8.9 \pm 0.3\end{array}$ & $\begin{array}{l}15.8 \pm 1.4 \\
16.8 \pm 1.5\end{array}$ \\
\hline Aorta $^{1}$ & $\begin{array}{l}\text { Ordinary egg } \\
\text { I-enriched egg }\end{array}$ & $\begin{array}{l}15.8 \\
15.1\end{array}$ & $\begin{array}{l}6.1 \\
6.3\end{array}$ & $\begin{array}{l}2.5 \\
2.4\end{array}$ & $\begin{array}{l}5.2 \\
5.1\end{array}$ \\
\hline
\end{tabular}

${ }^{\text {a }}$ Mean \pm SEM for 8 rats. ${ }^{1}$ The lipids in abdominal aorta were assayed on the pooled sample of each $50 \mathrm{mg}$ tissue from 8 rats. 


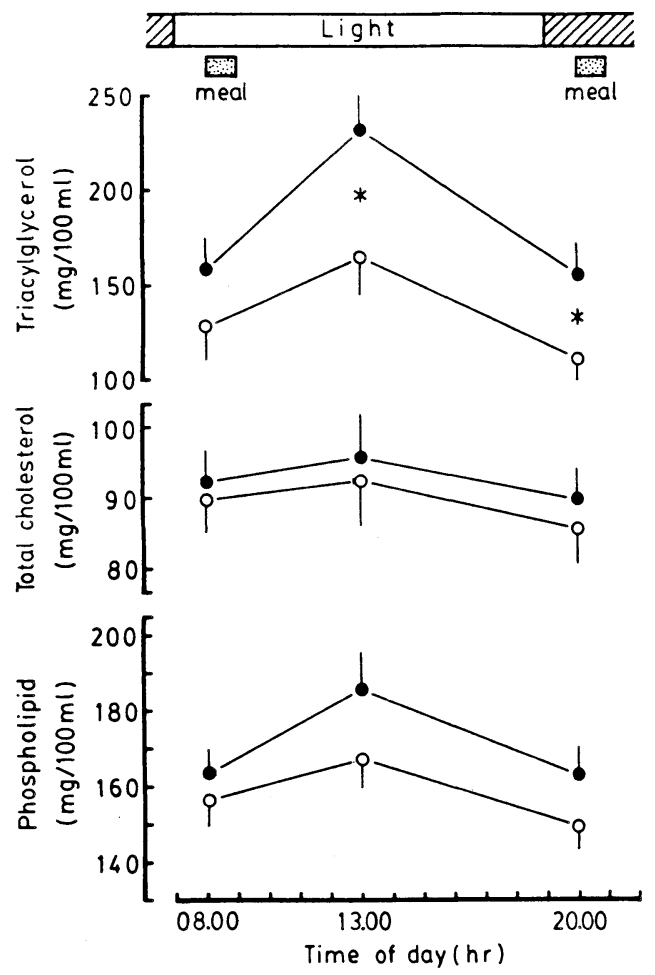

Fig. 2. Effect of the long-term (7 months) meal-feeding of an iodine-enriched egg diet on serum lipid levels of rats. Each point with a vertical line represents mean \pm SEM of 8 rats each. Ordinary egg diet group: $\bullet$. Iodine-enriched egg diet group: $\bigcirc$. ${ }^{*} p<0.05$ between the two dietary groups.

in heart appeared to be higher, after the experimental period of 7 months.

Serum TSH, thyroid hormone and total iodine concentrations, and thyroid total iodine content (Table 7)

The results obtained at $20.00 \mathrm{hr}$ on the day the rats were sacrificed after the 7month dietary treatment showed that serum TSH and thyroid hormone concentrations and thyroid total iodine content were not significantly different between the two dietary groups of animals, whereas the serum total iodine concentration was 5 times higher in the rats fed iodine-enriched eggs than that in controls.

\section{DISCUSSION}

The changes in the animal's voluntary running activity as shown in this study were similar to those observed in our previous experiment(1) and the study by Goodrick(14) on voluntary running exercise and longevity. The present study 
Table 5. Hepatic-intestinal triacylglycerol production rate and triacylglycerol removal rate in rats meal-fed an ordinary egg diet or an iodine-enriched egg diet for 9 months.

\begin{tabular}{|c|c|c|}
\hline & \multicolumn{2}{|c|}{ Dietary group } \\
\hline & $\begin{array}{c}\text { Ordinary } \\
\text { egg diet }(5)^{\mathrm{a}}\end{array}$ & $\begin{array}{l}\text { Iodine-enriched } \\
\text { egg diet (5) }\end{array}$ \\
\hline $\begin{array}{l}\text { TG production rate study } \\
\text { Plasma TG concentration }\end{array}$ & & \\
\hline $\begin{array}{l}\text { Initial } \\
\text { Final } \\
(\mathrm{mg} / 100 \mathrm{ml})\end{array}$ & $\begin{array}{l}175.2 \pm 31.0^{\mathrm{b}} \\
973.5 \pm 42.9\end{array}$ & $\begin{array}{l}140.4 \pm 29.4 \\
835.4 \pm 58.9^{\dagger}\end{array}$ \\
\hline $\begin{array}{l}\text { Production rate } \\
\text { (mg/min/rat) } \\
(\mu \mathrm{g} / \mathrm{min} / 100 \mathrm{~g} \text { body wt. })\end{array}$ & $\begin{array}{l}2.35 \pm 0.06 \\
408.5 \pm 6.4\end{array}$ & $\begin{array}{l}1.93 \pm 0.11^{* *} \\
355.6 \pm 17.7^{*}\end{array}$ \\
\hline $\begin{array}{l}\text { TG removal rate study } \\
\text { Plasma TG concentration }{ }^{2}\end{array}$ & & \\
\hline $\begin{array}{l}\text { Initial } \\
\text { Final } \\
(\mathrm{mg} / 100 \mathrm{ml})\end{array}$ & $\begin{array}{l}191.5 \pm 9.8 \\
129.5 \pm 11.0\end{array}$ & $\begin{array}{l}185.4 \pm 17.0 \\
102.8 \pm 19.0\end{array}$ \\
\hline $\begin{array}{l}\text { Removal } \text { rate }^{3} \\
(\mathrm{mg} / \mathrm{min} / \mathrm{rat}) \\
(\mu \mathrm{g} / \mathrm{min} / 100 \mathrm{~g} \text { body wt. })\end{array}$ & $\begin{array}{r}1.44 \pm 0.16 \\
254.0 \pm 24.8\end{array}$ & $\begin{array}{r}1.84 \pm 0.13^{\dagger} \\
338.5 \pm 17.1^{*}\end{array}$ \\
\hline
\end{tabular}

Body weights were $573.2 \pm 17.3 \mathrm{~g}$ and $545.6 \pm 27.0 \mathrm{~g}$ for ordinary egg diet group and iodine-enriched egg diet group, respectively, when the TG production rate experiment was made. And at the time of the TG removal rate experiment those were $568.9 \pm 16.5 \mathrm{~g}$ for ordinary egg diet group and $544.8 \pm 28.6 \mathrm{~g}$ for iodine-enriched egg diet group.

${ }^{1}$ Initial and final TG concentrations were measured on plasma samples obtained just before and $2 \mathrm{hr}$ after the Triton injection, respectively. The rats had received the oral administration of a $60 \%$ sugar mixture solution $3 \mathrm{hr}$ prior to the injection.

${ }^{2}$ Initial and final TG concentrations were measured on plasma samples obtained $15 \mathrm{~min}$ and $30 \mathrm{~min}$ after the intralipid injection, respectively.

${ }^{3} \mathrm{TG}$ production and TG removal rates were estimated by the following formulas:

TG production rate Final TG conc. $(\mathrm{mg} / \mathrm{ml})-$ Initial TG conc. $(\mathrm{mg} / \mathrm{ml})$ $(\mathrm{mg} / \mathrm{min} / \mathrm{rat})=\frac{120(\mathrm{~min})}{12} \times \mathrm{PV}_{\mathrm{E}}(\mathrm{ml} / \mathrm{rat})$

TG removal rate Initial TG conc. $(\mathrm{mg} / \mathrm{ml})-$ Final TG conc. $(\mathrm{mg} / \mathrm{ml})$ $(\mathrm{mg} / \mathrm{min} / \mathrm{rat})=\frac{15(\mathrm{~min})}{15} \times \mathrm{PV}_{\mathrm{E}}(\mathrm{ml} / \mathrm{rat})$

$\mathrm{PV}_{\mathrm{E}}$ (plasma volume) was calculated according to the equation reported by Bagdade $e t$ al. (12).

${ }^{\mathrm{a}}$ Number of rats. ${ }^{\mathrm{b}}$ Mean \pm SEM. ${ }^{*} p<0.05,{ }^{* *} p<0.02$, and ${ }^{\dagger} 0.05<p<0.10$ as compared to ordinary egg diet group.

revealed that an iodine-enriched egg diet as compared with an ordinary egg diet did not cause any excessive deposition of lipids or changes in the lipid compositions of the liver, kidney, brain, epididymal adipose tissue and aorta of rats.

In contrast, the 7-month feeding with iodine-enriched eggs decreased the mean levels of serum TG, total cholesterol and phospholipid as compared to the feeding 
Table 6. Effects of the long-term (7 months) meal-feeding of an iodine-enriched egg diet on lipoprotein lipase activities in soleus muscle, heart and epididymal adipose tissue.

\begin{tabular}{lcc}
\hline & \multicolumn{2}{c}{ Lipoprotein lipase activity } \\
\cline { 2 - 3 } & \multicolumn{2}{c}{ Dietary group } \\
\cline { 2 - 3 } & Ordinary & $\begin{array}{c}\text { Iodine-enriched } \\
\text { egg diet }(8)\end{array}$ \\
& egg diet $(8)^{\mathrm{a}}$ & $34.5 \pm 2.1^{*}$ \\
Soleus muscle & $(\mu \mathrm{mol} \mathrm{FFA} / \mathrm{hr} / \mathrm{g}$ of wet tissue $)$ \\
Heart & $27.1 \pm 2.2^{\mathrm{b}}$ & $133.8 \pm 11.4^{\dagger}$ \\
Epididymal adipose tissue & $111.2 \pm 4.1$ & $20.8 \pm 1.4^{* *}$ \\
\hline
\end{tabular}

${ }^{\mathrm{a}}$ Number of rats. ${ }^{\mathrm{b}}$ Mean \pm SEM. ${ }^{*} p<0.05,{ }^{* *} p<0.02$, and ${ }^{\dagger} 0.05<p<0.10$ as compared to ordinary egg diet group.

Table 7. Effects of the long-term (7 months) meal-feeding of an iodine-enriched egg diet on serum thyroid stimulating hormone, thyroid hormone and total iodine concentrations, and thyroid total iodine content.

\begin{tabular}{|c|c|c|c|}
\hline & & \multicolumn{2}{|c|}{ Dietary group } \\
\hline & & $\begin{array}{c}\text { Ordinary } \\
\text { egg diet }(8)^{\mathrm{a}}\end{array}$ & $\begin{array}{l}\text { Iodine-enriched } \\
\text { egg diet (8) }\end{array}$ \\
\hline Thyroid stimulating hormone & $(\mu \mathrm{U} / \mathrm{ml})$ & $3.6 \pm 0.4^{\mathrm{b}}$ & $2.8 \pm 0.3$ \\
\hline Thyroxine & $(\mu \mathrm{g} / 100 \mathrm{ml})$ & $4.5 \pm 0.2$ & $4.1 \pm 0.3$ \\
\hline Triiodothyronine & $(\mathrm{ng} / \mathrm{ml})$ & $1.0 \pm 0.1$ & $0.8 \pm 0.1$ \\
\hline Serum total iodine & $(\mu \mathrm{g} / 100 \mathrm{ml})$ & $6.1 \pm 0.3$ & $30.8 \pm 1.0^{* * *}$ \\
\hline Thyroid total iodine & ( $\mu \mathrm{g} / \mathrm{g}$ of wet tissue) & $1,058 \pm 213$ & $1,310 \pm 95$ \\
\hline
\end{tabular}

${ }^{a}$ Number of rats. ${ }^{\mathrm{b}}$ Mean \pm SEM. ${ }^{* * *} p<0.001$ as compared to ordinary egg diet group.

with ordinary eggs. The difference in the serum TG levels obtained at two out of three time points was found significant $(p<0.05)$ between the two dietary groups. This seemed to be possibly related to either a significant reduction of TG production rate or a significant elevation of TG removal rate which was determined after the 9month feeding of iodine-enriched eggs. The TG production rate measured here is considered to reflect the activity of hepatic and intestinal lipogenesis mainly from the ingested carbohydrate as well as the subsequent secretion of newly synthesized very low density lipoprotein-TG.

LPL activity relates to the peripheral removal of circulating lipoproteinTG (15). Our present data on tissue LPL activity were in accord with those of our previous study (1). A significantly elevated tissue LPL activity observed after the 7month feeding of iodine-enriched eggs may support the enhanced TG removal that 
was exhibited in the same dietary group of rats fed for 9 months.

It has been well documented that hyperlipemia is frequently associated with an increased TG production in man $(16,17)$ and rats $(11,12,18,19)$, and in part with an impaired peripheral TG removal in $\operatorname{man}(17,20,21)$ and rats (12). Therefore, the effects of iodine-enriched eggs on TG production, TG removal and tissue LPL activity in the present study may have an important role in the prevention of hyperlipemia.

Since the iodine-enriched egg diet contained fairly large amounts of iodine, the serum TSH, thyroid hormone and total iodine levels as well as the thyroid total iodine content were determined for their evaluations. However, no influence but a marked increase in the serum total iodine concentration was found with the 7month feeding of iodine-enriched eggs. Thus, it can be safely said that an iodineenriched egg diet might lower serum TG levels without any changes in serum thyroid hormone and TSH levels. However, whether the lowered serum TG level in the iodine-enriched egg fed animals might be related with the highly elevated serum iodine level is not known.

In conclusion, it is suggested that the lowering effect of serum TG level with feeding of iodine-enriched eggs in rats may be mediated by a reduced hepaticintestinal TG production as well as an enhanced peripheral removal of circulating TG.

Studies are under way to further define the nutritional consequences of the feeding of iodine-enriched eggs for a longer-period in rats.

We thank Messrs. T. Kajuu, K. Okamura, K. Ide and Y. Satoh for their kind cooperation. This work was conducted at the University of Tsukuba mainly by S. Katamine who was an entrusted researcher $(1980,1981)$ supported by the Ministry of Education, Science and Culture of Japan and received research training from Prof. Dr. M. Suzuki.

\section{REFERENCES}

1) Katamine, S., Hoshino, N., Totsuka, K., and Suzuki, M. (1981): Effect of iodine enriched eggs on lipid metabolism of growing rats at exercise and meal. Eiyo to Shokuryo (J. Jpn. Soc. Food Nutr.), 34, 295-302.

2) Suzuki, M., Hashiba, N., and Kanno, S. (1981): Effect of various feeding patterns on circadian rhythm of voluntary running activity in rats. Bull. Inst. Health Sport Sci., Univ. Tsukuba, 4, 155-169.

3) Fletcher, M. J. (1968): A colorimetric method for estimating serum triglycerides. Clin. Chim. Acta, 22, 393-397.

4) Zurkowski, P. (1964): A rapid method for cholesterol determination with a single reagent. Clin. Chem., 10, 451-453.

5) Folch, J., Lees, M., and Sloane-Stanley, G. H. (1957): A simple method for the isolation and purification of total lipides from animal tissues. J. Biol. Chem., 226, 497-509.

6) Suzuki, M., Hashiba, N., and Kajuu, T. (1982): Influence of timing of sucrose meal feeding and physical activity on plasma triacylglycerol levels in rats. J. Nutr. Sci. Vitaminol., 28, 295-310. 
7) De Gasquet, P., and Péquignot, E. (1972): Lipoprotein lipase activities in adipose tissues, heart and diaphragm of the genetically obese mouse $(o b / o b)$. Biochem. J., 127, 445-447.

8) Trout, D. L., Estes, E. H., Jr., and Friedberg, S. J. (1960): Titration of free fatty acids of plasma: A study of current methods and a new modification. J. Lipid Res., 1, 199-202.

9) Acland, J. D. (1957): The estimation of serum protein-bound iodine by alkaline incineration. Biochem. J., 66, 177-188.

10) Fischer, P. W. F., and L'abbé, M. R. (1981): Acid digestion determination of iodine in foods. J. Assoc. Off. Anal. Chem., 64, 71-74.

11) Simonelli, C., and Eaton, R. P. (1978): Reduced triglyceride secretion: A metabolic consequence of chronic exercise. Am. J. Physiol., 234, E221-E227.

12) Bagdade, J. D., Yee, E., Albers, J., and Pykalisto, O. J. (1976): Glucocorticoids and triglyceride transport: Effects on triglyceride secretion rates, lipoprotein lipase, and plasma lipoproteins in the rat. Metabolism, 25, 533-542.

13) Carlson, L. A., and Rössner, S. (1972): A methodological study of an intravenous fat tolerance test with Intralipid emulsion. Scand. J. Clin. Lab. Invest., 29, 271-280.

14) Goodrick, C. L. (1980): Effects of long-term voluntary wheel exercise on male and female Wistar rats. I. Longevity, body weight, and metabolic rate. Gerontology, 26, $22-33$.

15) Robinson, D. S., and Wing, D. R. (1971): Studies on tissue clearing factor lipase related to its role in the removal of lipoprotein triglyceride from the plasma. Biochem. Soc. Symp., 33, 123-135.

16) Reaven, G. M., Hill, D. B., Gross, R. C., and Farquhar, J. W. (1965): Kinetics of triglyceride turnover of very low density lipoproteins of human plasma. J. Clin. Invest., 44, 1826-1833.

17) Nikkila, E. A. (1974): Metabolism of plasma triglycerides in endogenous hypertriglyceridemia. Horm. Metab. Res., Suppl. Ser., 4, 29-34.

18) Schonfeld, G., and Pfleger, B. (1971): Overproduction of very low-density lipoproteins by livers of genetically obese rats. Am. J. Physiol., 220, 1178-1181.

19) Robertson, R. P., Gavareski, D. J., Henderson, J. D., Porte, D., Jr., and Bierman, E. L. (1973): Accelerated triglyceride secretion: A metabolic consequence of obesity. J. Clin. Invest., 52, 1620-1626.

20) Harlan, W. R., Jr., Winesett, P. S., and Wasserman, A. J. (1967): Tissue lipoprotein lipase in normal individuals and in individuals with exogenous hypertriglyceridemia and the relationship of this enzyme to assimilation of fat. J. Clin. Invest., 46, 239-247.

21) Pykalisto, O. J., Smith, P. H., and Brunzell, J. D. (1975): Determinants of human adipose tissue lipoprotein lipase: Effect of diabetes and obesity on basal- and dietinduced activity. J. Clin. Invest., 56, 1108-1117. 